\title{
PENGEMBANGAN DESAIN PERHIASAN TEMBAGA INSPIRASI TEKNIK FILIGREE DENGAN PENDEKATAN EKSPLORASI
}

\author{
${ }^{1}$ Yayang Murdiyanto, ${ }^{2}$ Dedy Ismail \\ Jurusan Desain Produk, Fakultas Seni Rupa dan Desain, ITENAS, Bandung. \\ Jurusan Desain Produk, Fakultas Seni Rupa dan Desain, ITENAS, Bandung. \\ Email : ${ }^{1}$ murdyiantosukarto@gmail.com ${ }^{2}$ dedy_sml@yahoo.co.id
}

\begin{abstract}
ABSTRAK
Perhiasan Filigree memiliki karakter perhiasan yang kompleks dan mendetail, sehingga segmentasi pasar terbatas pada rentang usia dewasa kalangan menengah atas. Penelitian ini berperan penting sebagai salah satu teknik dan metode pengumpulan data yang akan dikaji pada proyek perancangan selanjutnya. Tujuan dilakukannya pengembangan teknik filigree dengan pendekatan new material adalah untuk memperluas jangkauan pasar. Selain pendekatan material baru, pengembangan desain perhiasan teknik filigree ini. Metode penelitian desain yang dilakukan adalah pengumpulan data melalui observasi, wawancara, dokumentasi, studi literasi dan eksplorasi. Hasil penelitian ini menunjukkan bahwa perhiasan teknik filigree dapat berkembang mengikuti perkembangan trend dan bisa menjangkau segmentasi pasar yang lebih luas sehingga bisa menambah nilai produk dan kualitas hidup pengrajin logam.

Kata kunci: Desain Perhiasan, Pengembangan, Filigree.
\end{abstract}

\section{ABSTRACT}

Filigree jewelry has a complex and detailed jewelry character, so the market segment is limited to the adult span of the upper middle class. This study plays a very important role as one of the techniques and data-collection methods that are being studied in a student of v's design project. The purpose of developing filigree techniques with a materials mix approach is to expand the market's reach. Aside from a media mix approach, the development of this filigree piece of jewelry design. The design design method is done is observation, interviews, documentation, literacy and exploration studies. This study suggests that highgree jewelry can develop with trends and can reach a broader market segment so that it can enhance market value and quality of metal craftsmen 'lives.

Keywords: Jewelry Design, Development, Filigree.

\section{PENDAHULUAN}

Teknik Filigree sudah muncul sejak abad ke-6 sebelum Masehi melalui berbagai perhiasan terutama gelang yang saat ini disimpan dalam British Museum. Sejumlah anting-anting dan ornamen pribadi lainnya yang ditemukan di Italia saat ini dilestarikan di Museum Louvre dan di British Museum hampir semuanya juga merupakan karya Filigree. Beberapa ciri dari artefak filigree tersebut mengambil bentuk floral berdesain geometris dibatasi oleh satu atau lebih frame yang masing-masing terdiri dari kawat logam dengan ukuran kecil dan ornamen yang bervariasi. (Maryon, 1971) Namun teknik Filigree kurang mengikuti perkembangan jaman, mengingat trend-trend perhiasan terus berkembang seperti, earcuff, heavyhole, pile. Kurang populernya Filigree ini juga dipengaruhi oleh bentuk-bentuk perhiasannya yang masih tetap mengambil inspirasi desain-desain dahulu.

Perkembangan-perkembangan kerajinan perak produksi rumahan yang ada di desa Pampang Yogyakarta dilihat dari adanya pengembangan-pengembangan dari desain yang menerapkan dan menggabungkan beberapa jenis ragam hias 98 mulai dari desain kotemporer, tradisional, dan desain kotemporer gabungan dengan desain tradisional. Di dusun Pampang Yogyakarta memiliki karakteristik karya yang berkembang dinilai dari adopsi motif-motif tradisional dengan penggunaan dan penggabungan berbagai jenis bahan yaitu perak dan tembaga, serta menambahkan atau mengkombinasi dengan bahan tekstil, kayu, batu, dan manik-manik. (Nasai, 2018)

Perhiasan memiliki bentuk beragam mulai dari bulat, hati, dan kotak, dan pada umumnya terbuat dari bahan tambang, pada masa-masa dahulu banyak digunakan sebagai lambang kepala suku, benda pusaka, dan memperindah pakaian dan penampilan. Fungsi tersebut hingga kini di gunakan, selain untuk menambah menarik perhatian, dan juga digunakan untuk menjadi ciri khas atau identitas pemakainya.
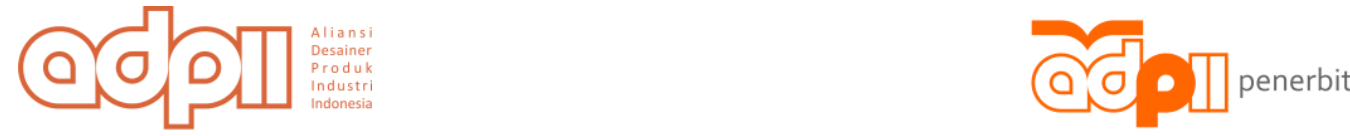
Sedangkan Filigree adalah teknik pembuatan perhiasan perak dengan menggunakan peralatan yang masih sederhana (tradisional), dan sebagian besar pengerjaannya masih dilakukan secara manual. Hal ini berpengaruh pada segmentasi pasar yang membuat harga perhiasan dengan teknik ini menjadi mahal. Di Asia, pembuatan benda pakai yang menggunakan keterampilan motorik tangan (kerajinan) juga mengalami nasib yang sama. Walaupun craft menjadi cikal-bakal landasan pertumbuhan indutri, namun craft semakin tidak bisa memenuhi kebutuhan pertumbuhan industrial modern. (Masri \& Pasaribu, Page | 18 2018)

\section{METODOLOGI}

Metode yang digunakan dalam penelitian ini adalah menggabungkan metode berfikir Double Diamond Design Process dengan studi literasi, observasi, dan ekplorasi/eksperimen tentang teknik Filigree, penelitian ini juga menganalisis kembali potensi-potensi yang dimiliki oleh Filigree sebagai teknik pembuatan perhiasan yang telah berkembang di Indonesia dari tahun $80 a n$. Selain itu penulis juga melakukan serangkaian analisis terstruktur mengenai fenomena sosial dan trend-fashion yang sedang berkembang.

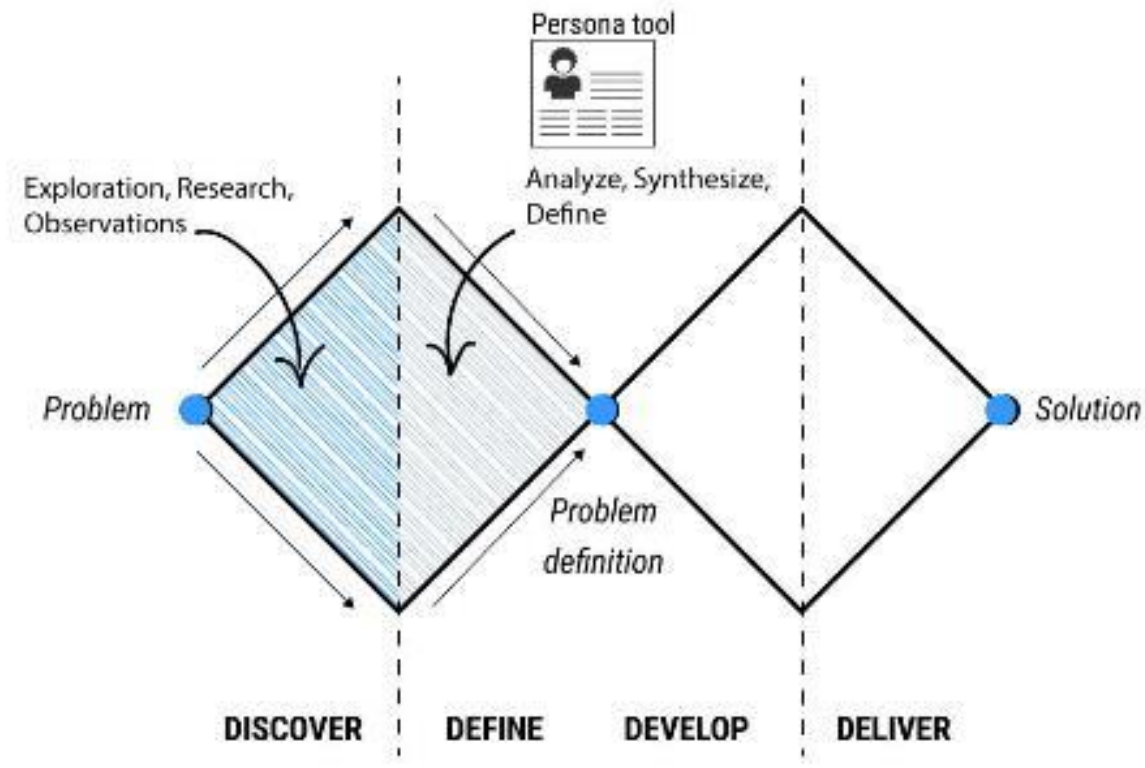

\section{Gambar 1. Alur Metode Design}

\section{Discover}

Dalam tahap yang pertama ini penulis akan membuat rencana dengan mencari penemuan baru berupa ide, masalah, ataupun tantangan, namun sebelum memilih temuan untuk dikaji, penulis perlu memahaminya terlebih dulu.

Define

Pada tahap ini penulis menetapkan masalah yang akan diselesaikan sesuai dengan prioritas. Proses ini dilakukan dengan mengumpulkan semua hasil riset di tahap sebelumnya, mengolah, mengelompokkan dan menganalisisnya.

Develop

Pada tahap ini penulis mengumpulkan ide-ide yang kreatif, melalui sesi brainstorming, untuk selanjutnya dievaluasi mana yang paling layak/bisa dilaksanakan.

Deliver

Ditahap terakhir ini penulis membuat prototype dari produk yang dijadikan solusi desain, namun tidak menutup kemungkinan untuk kembali ketahap develop apabila produk dirasa kurang atau tidak memecahkan masalah awal yg sudah direncanakan.
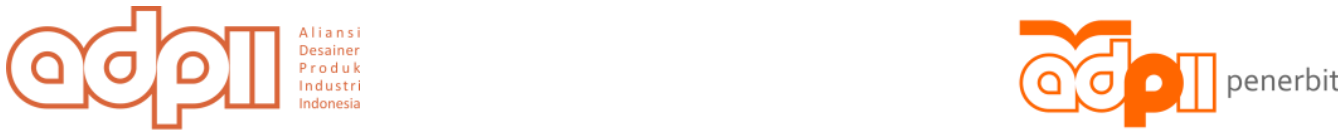


\section{HASIL DAN PEMBAHASAN}

Kerajinan Tembaga, Kuningan dan Logam lainnya, memiliki banyak potensi untuk dijadikan sebuah karya, baik berupa perhiasan maupun produk yang dipakai sehari-hari. Di Yogyakarta kerajinan perak telah lahir sejak jaman berdirinya kesultanan Yogyakarta. Hal tersebut mendorong terkenalnya kota Yogyakarta selain sebagai Kota Pelajar, Kota Wisata juga disebut Kota Perak. Kerajinan ini memiliki nilai budaya daerah yang sangat tinggi. Hal ini dapat dilihat dari jenis ornament yang diukir pada kerajinan khas Yogyakarta. Sisi lain yang menarik adalah karena proses pengerjaan sebagian masih menggunakan peralatan tradisional namun justru memiliki nilai keindahan dan nilai seni yang tinggi. (Evi Yuliati Rufaida, 2009)

Perak murni mempunyai sifat-sifat sebagai berikut ; symbol Ag ( Argentum) berupa butiran-butiran kecil berwarna putih, mudah larut dalam asam nitrat, titik lebur $963^{\circ} \mathrm{C}$, berat jenis 10,5 , berat atom 107,88 . Tembaga mempunyai sifat-sifat; symbol Cu (Cuprum), warna merah kekuningan, titik lebur 1083 ㅇ, berat jenis 7,84, tembaga bereaksi dengan udara kering pada temperature kamar. Produk yang menggunakan bahan baku perak murni harganya lebih mahal bila dibandingkan dengan yang menggunakan bahan baku dari Tembaga atau Kuningan ataupun tembaga yang dilapis (platting) Perak.

Pembuatan kawat logam dilakukan dengan cara menuangkan logam yang sudah dileburkan, kemudian dituangkan pada singen/cetakan. Ukuran cetakan disesuaikan dengan dimensi produk kawat yang akan digunakan agar dapat dicapai diameter kawat yang dikehendaki. Hasil peleburan diperpanjang dengan cara ditempa (dipukul) dengan palu sampai cukup kecil untuk dapat dimasukkan dalam lubang besi. (Evi Yuliati Rufaida, 2009)

Tabel 1. Hasil uji kadar logam perak dan tembaga (\%) produk kawat

\begin{tabular}{|l|l|l|}
\hline No & Komposisi (gram) & Kadar rata-rata (\%) \\
\hline & Perak $:$ Tembaga $=100: 2$ & 96,8 \\
\hline & Perak $:$ Tembaga $=100: 1,5$ & 97,2 \\
\hline & Perak $:$ Tembaga $=100: 1$ & 97,8 \\
\hline
\end{tabular}

Produk perhiasan perak filigree yang sudah ada dipasaran dapat dilihat pada gambar berikut;
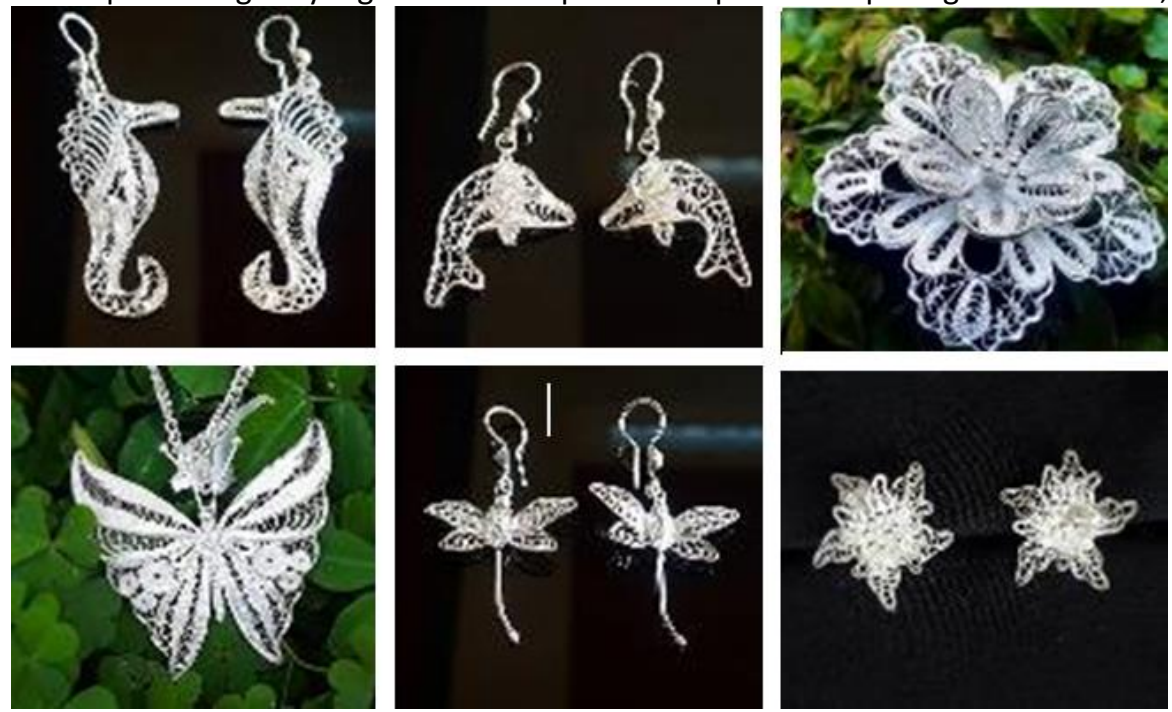

Gambar 2. perhiasan filigree dengan konsep fauna \& flora (Sumber : www.hssilver.com)

Pada gambar di atas terlihat bahwa bentuk perhiasan filigree yang sudah ada di pasaran memiliki kecenderungan desain complex, berlayer, dan elderly. Hal ini pula yang menyebabkan kurangnya peminat dari anak-anak muda. Selain itu sudah dijelaskan bahwa perhiasan yang bahan bakunya terbuat dari perak murni harganya lebih mahal dibandingkan dari tembaga dan kuningan, yang berpengaruh pada segmentasi pasar yang menjadi terbatas, artinya hanya kalangan tertentu saja yang mampu membeli perhiasan dengan konsep filigree. Filigree juga memiliki beberapa pakem (ketetapan) ataupun
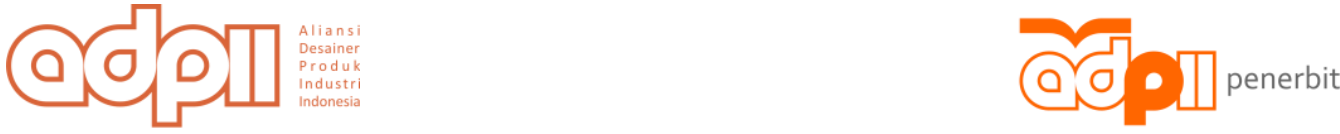
bisa dijadikan sebagai prinsip yang dimiliki teknik ini; quilling, wirering, pengulangan, stripes, dan berbentuk benang perak.

\subsection{Pencarian Desain}

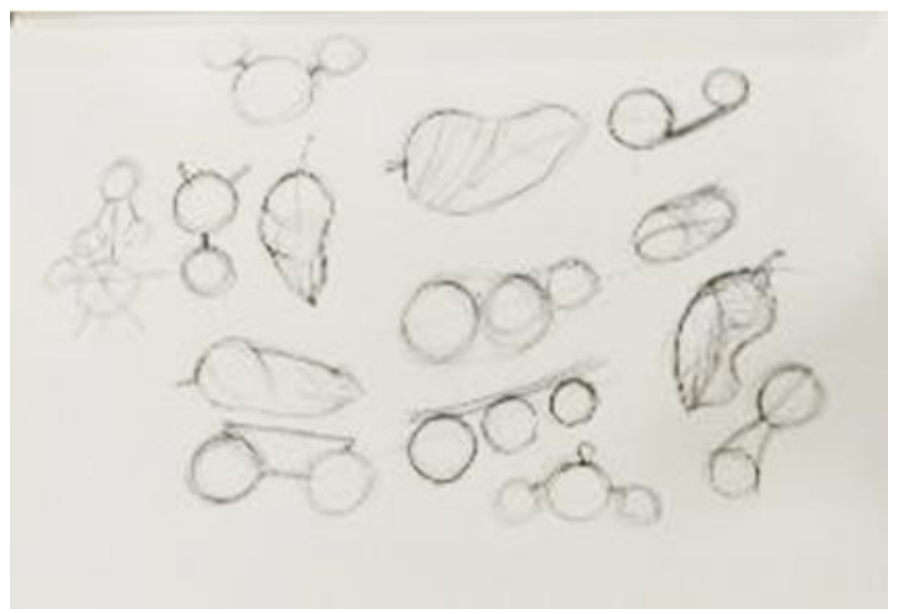

Gambar 3. Sketsa pencarian

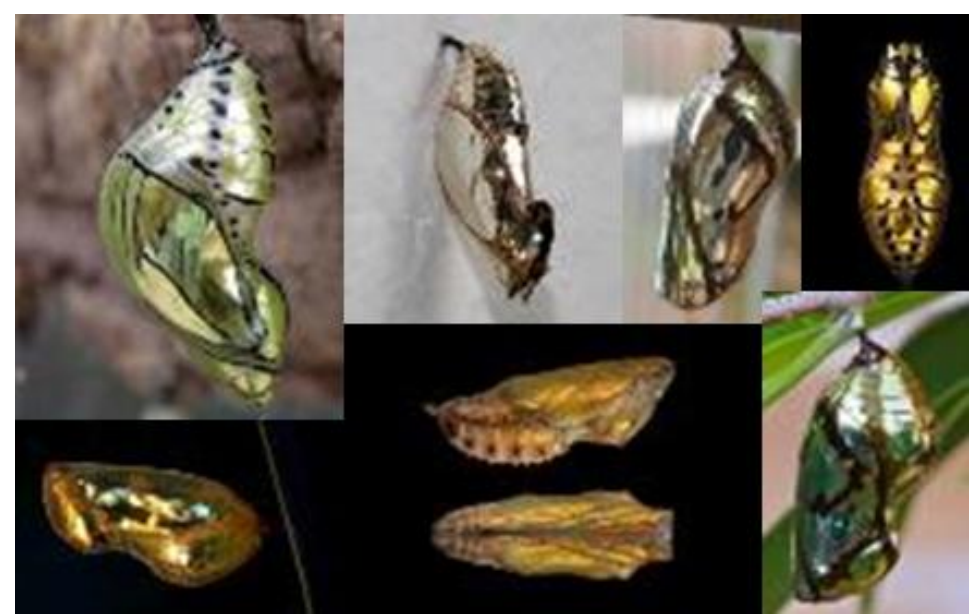

Gambar 4. Image board

Pencarian desain yang dilakukan adalah dengan metode metafora. Pengembangan desain melalui metoda metafora ini dapat diaplikasikan pada desain produk-produk yang dihasilkan oleh industriindustri kecil seperti misalnya produk mug yang dibuat oleh industri kecil keramik. (Waskito, 2014) Mug yang terinspirasi dari belalai gajah, penulis mengambil inspirasi dari fauna yaitu kepongpong "pupa" proses ini adalah salah satu dari rangkaian motede yang akan dikaji, diproses ini memulai pencarian bentuk-bentuk yang khas yang dimiliki pupa untuk kemudian dijadikan sebagai desain perhiasan.
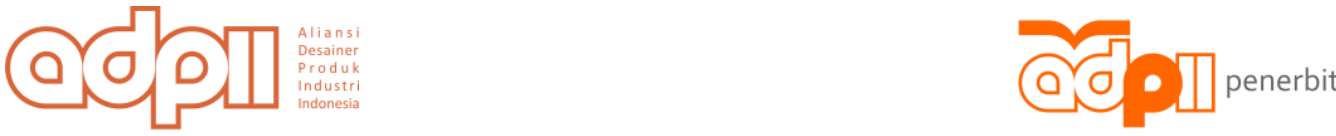

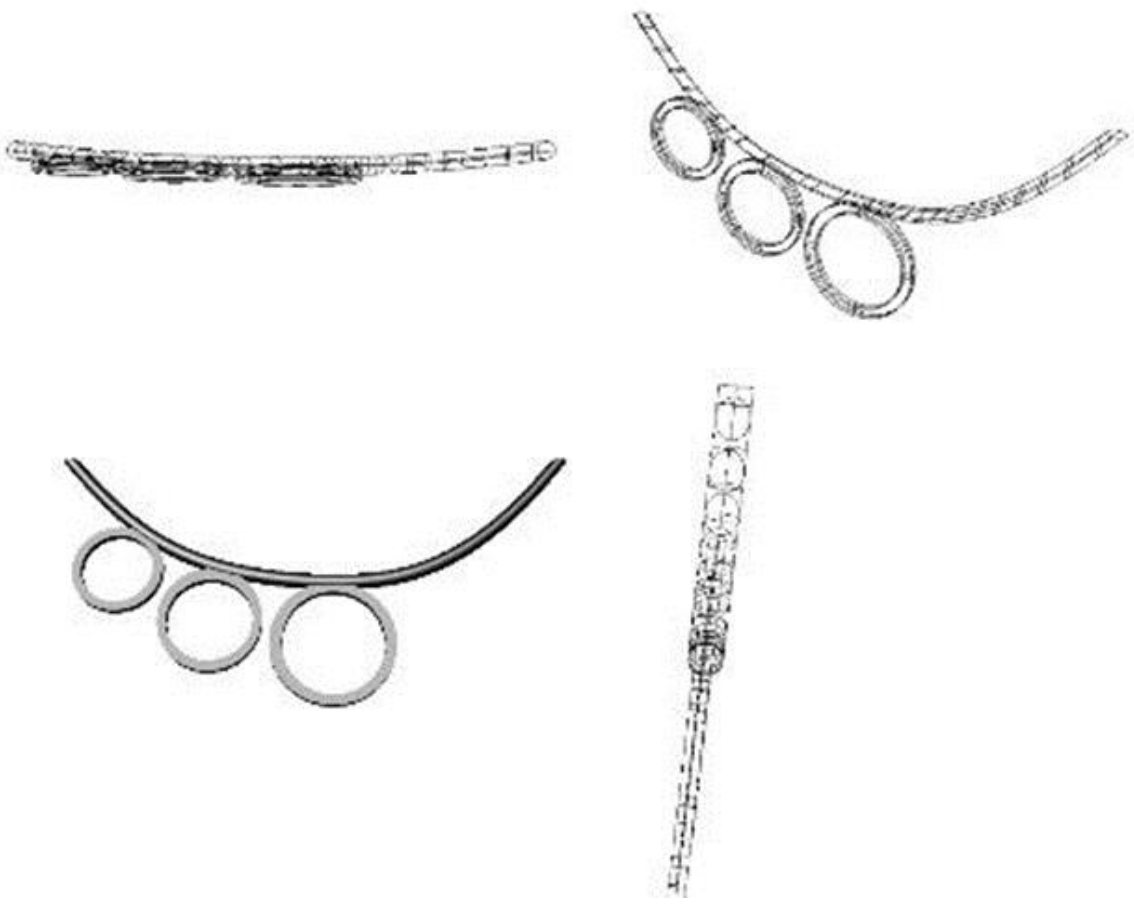

Gambar 5. Visualisasi Desain Terpilih

Disimpulkan bahwa desain terpilih inilah yang kemudian akan dijadikan produk perhiasan baru, mengisi lubang kosong pada bagian bundar dengan prinsip teknik filigree quilling kawat-kawat untuk kemudian dipatri.

Penetapan bahan dan material dari problem yang dikaji, material Logam Tembaga dan Kuningan dinilai paling efektif untuk menjadi bahan baku utama dalam pembuatan produk ini.

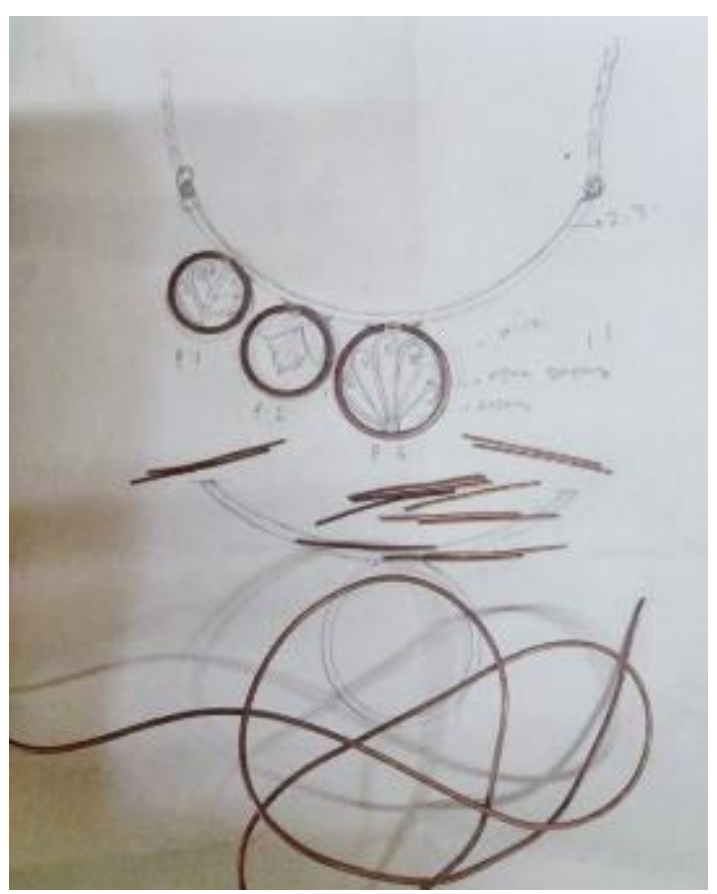

Gambar 6. Ekperimen I Pembentukan Frame
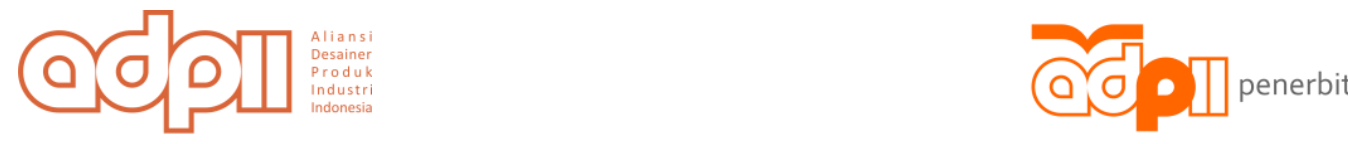
Dalam tahap ini kawat dengan ukuran $0.3 \mathrm{~mm}$ digunakan sebagai bagian luar (bingkai/frame) untuk diisi kawat yang diameternya lebih kecil. Kawat kecil ini menjadi pengganti benang-benang perak pembentuk filigree.

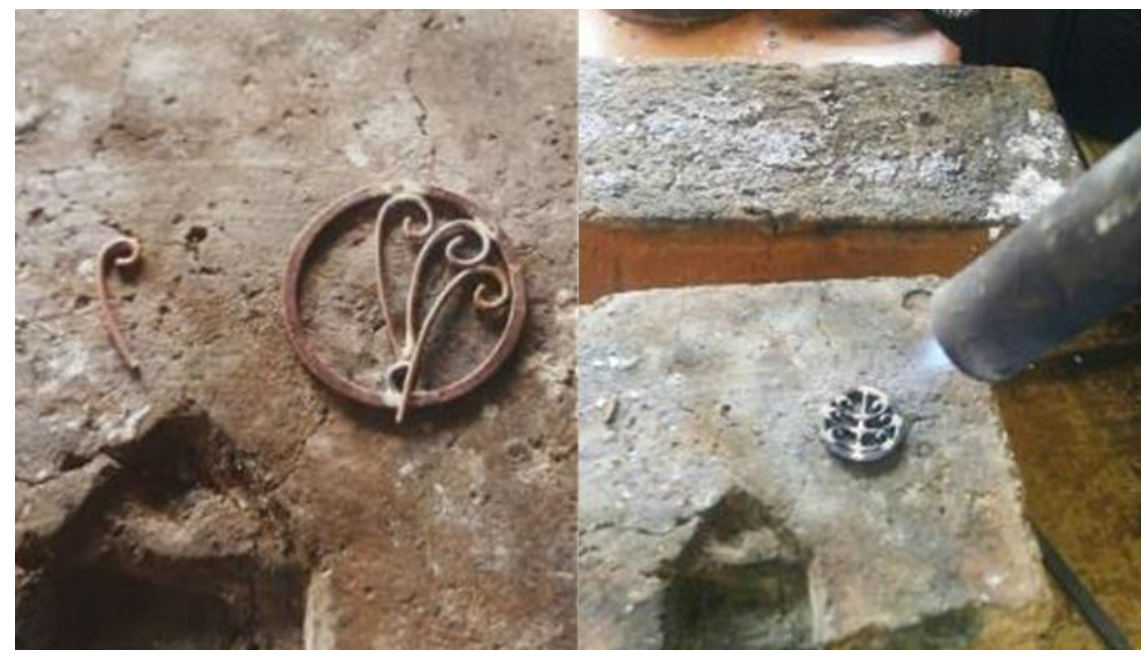

Gambar 7. Eksperimen II

Kawat yang sudah menjadi frame kemudian disatukan dengan kawat yang sudah digulung penyatuan inilah yang disebut juga "patri". Kawat-kawat logam yang berukuran kecil disusun dan dipanaskan dengan suhu $180 \stackrel{\circ}{\circ}$.

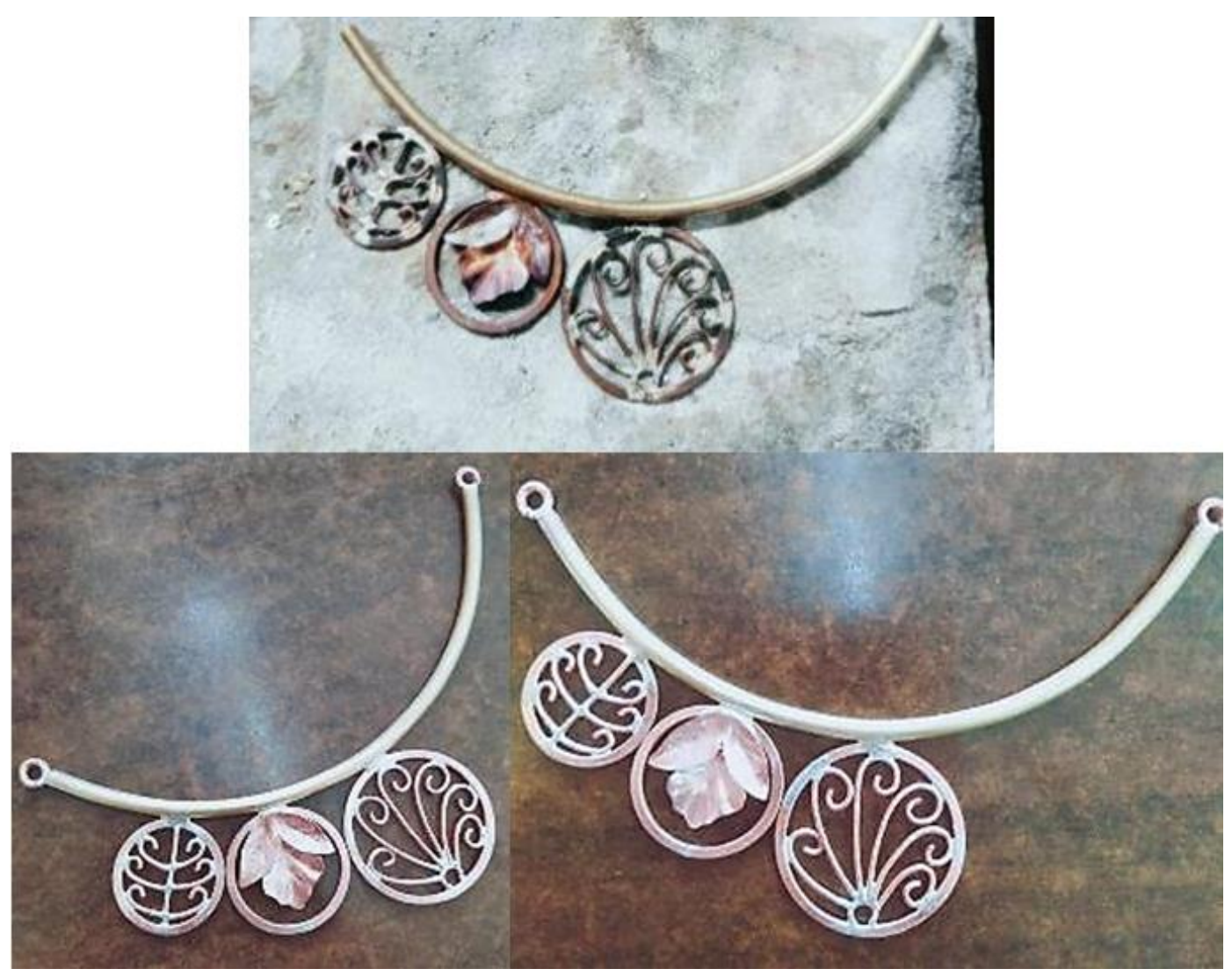

Gambar 8. Hasil Akhir Pengembangan Desain Terpilih
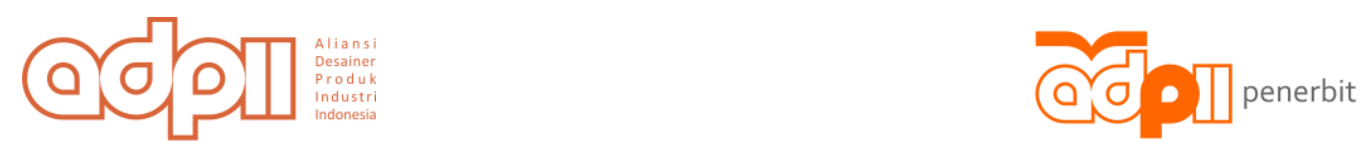


\section{KESIMPULAN}

Berdasarkan metode dan hasil observasi diperoleh data bahwa perhiasan perak filigree memiliki segmentasi pasar yang cukup sempit dikarenakan perhiasan dengan teknik ini memiliki pakem (ketetapan) seperti; benang perak, layering, wirering, dan complex. Desain yang sudah ada di pasaran juga masih terpaku pada bentuk desain yang lama. Selain itu, mahalnya perhiasan yang menggunakan bahan baku perak, menjadikan perhiasan ini hanya diminati oleh pembeli usia 30-60 tahun dengan tingkat ekonomi menengah ke atas. Melihat permasalahan ini, maka muncul peluang untuk memperluas segmentasi pasar dengan melakukan serangkaian eksperimen pengembangan teknik filigree dengan material logam tembaga dan kuningan, karena logam jenis ini paling cocok untuk menggantikan logam perak. Adanya kebaruan desain filigree dengan material alternatif selain dapat memperluas segmentasi pasar juga dapat menekan dana produksi bagi para pengrajin.

\section{DAFTAR PUSTAKA}

Evi Yuliati Rufaida, S. I. (2009). Balai Besar Kerajinan dan Batik Yogyakarta. PEWTER UNTUK KERAJINAN PERHIASAN , 2.

Maryon, H. (1971). In Filigree : Metalwork and Enameling (5 ed., p. 9). Dover Press.

Masri, A., \& Pasaribu, Y. M. (2018). Kerajinan, kraft, kriya, dan desain. CRAFT DAN DESAIN DI INDONESIA, SUDUT PANDANG AKADEMIS DAN PELAKU, 18.

Nasai, I. (2018). Kesimpulan. KERAJINAN PERAK PRODUKSI RUMAHAN DI PAMPANG, PALIYAN, GUNUNGKIDUL, 97-98.

Waskito, M. A. (2014). Pendekatan Semantik Rupa Sebagai Metoda Pengembangan Desain Produk Dengan Studi Kasus Produk Mug di Industri Kecil Keramik. 5.

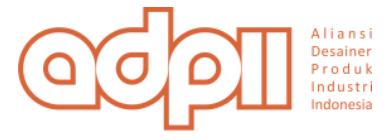

